to roll

in the wet ashes of the father, wet with the death of the father, and not try

to burn my way upward; the son, rising.

I swear to you now, I will survive,

rise up, and chant my way through these losses;

and you, you, brother, whatever that is, same blood, you who swim

in the same waters,

you promise me to make your music too,

whatever the hurt;

O when we are almost only

mouth, when we are almost only a head

stuck on the pole of the body,

and the man says "Talk to me, baby,"

let's refuse him, brother, both, all of us,

and striking the spine like an instrument, inside,

like birds, with even the body broken,

our feathers fiery-there! there!-among

the leaves and branches, make

no sounds he will know;

like birds, my brother, birds of the new world, sing.

\title{
S. Eliason 66: Double Portrait of Emily Dickinson and the Rev. Charles Wadsworth / Jane Cooper
}

She is just leaving the room.

He fades to a china cup.

Velocity fraught with gold,

with menace of Light, atomic secrets-

An aroused skin opens over the Great Plains,

October leaves rain down. 
Corn in conflagration!

The great retreats of the Civil War!

Marriage in conflagration!

Years-An empty canvas.

She scrawls across radiant space

E ... I ... SON! I made this, the date, name within name.

\title{
The Day the Air Was on Fire / Reg Saner
}

\author{
All afternoon neither of us said \\ "This air's on fire," though both felt it \\ and felt in sunlight like that, death \\ was impossible, or if possible, overrated, \\ even trivial. The sky kept showing off \\ in all colors, each of them blue \\ and we trekked that enormous plateau \\ whose tundra darkened or flared in one broad \\ autumnal crackle of burnt orange, then gold, \\ drifting under islands of cumulus \\ as if somebody'd laid out the pelt \\ from a sunset. Towards the nearest of two \\ schist cairns studding the highest stretches \\ we knelt and touched late gentian corollas, \\ still half bud. "How long till first snow?" \\ Days, not weeks. But with outcrops insisting \\ the last word should be stone, then flaking \\ and falling away from that, we noticed \\ how each tuft put them to use \\ improvising soil from palmfuls of grit, \\ saying "If not this season, the next- \\ perhaps the one after," and coming on \\ very small, coming on uphill, \\ against everything.
}

